\section{Body construction and health itineraries: a survey among travestis and trans people in Rio de Janeiro, Brazil}

\author{
A construção do corpo e itinerários de saúde: \\ um estudo entre travestis e pessoas trans \\ no Rio de Janeiro, Brasil
}

\author{
Construcción corporal e itinerarios de salud: \\ una encuesta entre travestis y personas \\ trans en Río de Janeiro, Brasil
}

\author{
Sérgio Carrara 1,2 \\ Jimena de Garay Hernandez 1 \\ Anna Paula Uziel 1 \\ Greice Maria Silva da Conceição 3 \\ Henri Panjo 4 \\ Ana Camilla de Oliveira Baldanzi 5 \\ João Pedro Queiroz 5 \\ Luisa Bertrami D’Angelo 6 \\ Adriana Maria Shad e Balthazar 1 \\ Aureliano Lopes da Silva Junior 1 \\ Alain Giami 4
}

doi: 10.1590/0102-311X00110618

\begin{abstract}
The article examines health itineraries followed by Brazilian travestis, trans men and trans women in the affirmation of their gender, based on the survey Trans Uerj: Health and Citizenship of Trans People in Brazil. The survey's main objectives were to gauge the trans/travesti population's diversity and sociodemographic profile; and to map the various ways they access their rights as citizens, especially to healthcare services and body modification technologies. Interviewers, mainly trans people and travestis, applied 391 questionnaires in the city of Rio de Janeiro and its metropolitan region to interviewees of different social classes, schooling levels and gender identity configurations, contacted through the interviewers' social networks. For defining respondents' gender identities the survey used an original method based on self-definitions, which were then aggregated into 6 categories for data analysis purposes. This article discusses the multiple strategies used by this trans population in gender affirmation processes to gain access to regulated and/or unregulated use of hormones and surgical procedures.
\end{abstract}

Transgender Persons; Gender Identity; Sex Reassignment Procedures

\author{
Correspondence \\ S. Carrara \\ Laboratório de Diversidade Sexual e de Gênero, Políticas e \\ Direitos, Universidade do Estado do Rio de Janeiro. \\ Rua São Francisco Xavier 524, Bloco D, 7o andar, \\ Rio de Janeiro, RJ 20550-013, Brasil. \\ scarrara1@gmail.com \\ ${ }^{1}$ Laboratório de Diversidade Sexual e de Gênero, Políticas \\ e Direitos, Universidade do Estado do Rio de Janeiro, Rio de \\ Janeiro, Brasil. \\ 2 Instituto de Medicina Social, Universidade do Estado do Rio de \\ Janeiro, Rio de Janeiro, Brasil. \\ 3 Instituto de Tecnologia em Imunobiológicos, Fundação \\ Oswaldo Cruz, Rio de Janeiro, Brasil. \\ ${ }_{4}^{4}$ Centre de Recherche en Épidémiologie et Santé des Populations, \\ Institut National de la Santé et de la Recherche Médicale, \\ University Paris Saclay - F- 94807 Villejuif, Paris, France. \\ 5 Instituto de Psicologia, Universidade do Estado do Rio de \\ Janeiro, Rio de Janeiro, Brasil. \\ 6 Programa de Pós-graduação em Psicologia Social, \\ Universidade do Estado do Rio de Janeiro, Rio de Janeiro, Brasil.
}




\section{Introduction}

This article presents the first analysis conducted in the context of the international research project Trans Uerj: Health and Citizenship of Trans People in Brazil - A Brazil/France Comparative Approach undertaken by the State University of Rio de Janeiro (UERJ/Brazil) in collaboration with the National Institute of Health and Medical Research (Institut National de la Santé et de la Recherche Médicale - INSERM/France) and National Agency for Recherche on AIDS and Hepatitis (Agence Nationale de Recherche sur le SIDA et les Hépatites - ANRS/France). In addition to an ethnographic study not addressed in this article, a survey was conducted among the trans population of Rio de Janeiro and its metropolitan region. Unlike other surveys carried out recently in Brazil 1,2, our study included not only travestis and trans women, but also trans men and non-binary people.

The study's objective involved ascertaining this population's sociodemographic profile, while also understanding (i) its mechanisms of access to available healthcare services, especially body modification and HIV/AIDS detection and prevention technologies; and (ii) its exercising of other civil rights, especially those involving name and/or gender alteration on official documents. Using the data produced by this survey, the present article will focus on discussing the health itineraries followed by the interviewees in their gender affirmation processes.

Instead of the term "therapeutic itinerary" 3 , which is already well-established in the public health field, we adopt the term "health itinerary". This is meant as a critique of pathologizing approaches to trans/travesti experiences and identities, stressing that the paths followed by this population in its gender affirmation strategies are crucial for the promotion of health in a broader sense.

\section{Methodology}

The survey entailed the development of a 136-item questionnaire, with only one open-ended question (eliciting gender self-identification). In order to facilitate future comparisons in Brazil and internationally, a previously used French questionnaire was used as a basis ${ }^{4}$. During a pilot stage in Rio de Janeiro in 2014, this questionnaire was translated into Portuguese and adapted to the Brazilian context through discussions with the UERJ research team, leaders of Brazilian trans and travesti social movements, and professionals of the legal, health and social services accessed by this population. Still in the pilot stage, the questionnaire was applied to 23 trans and travesti people.

In addition to sociodemographic data, the questionnaire addresses information about (i) schooling and employment; (ii) body (re)construction processes; (iii) general health conditions (emphasizing aspects related to exposure to HIV and other STIs); (iv) sexual practices and representations of sexuality; (v) experiences of violence or discrimination and access to civil rights, such as name and gender changes on official documents.

After approval by the Brazilian National Ethics Research Committee (CONEP), an Advisory Committee comprised mostly of travestis and transsexuals was set up. General strategies for applying the questionnaire as well as interviewer recruitment criteria were discussed with the advisory committee. Following the committee's recommendation, the team of 15 interviewers was comprised almost entirely of trans men (5) and trans women/travestis (7), as well as 3 cisgender persons ( 2 women and $1 \mathrm{man})$, who applied only four questionnaires.

The interviewers, selected among committee nominations, included people of various ethnic and racial identities, social backgrounds, age groups and schooling levels. This interviewer selection procedure was designed to achieve three ethical, political, and methodological aims: (i) to contest the historically assigned place of this population as an "object of study," recognizing their role in the research as agents who produce knowledge based on their own experiences; (ii) to create a safe and empathetic environment for the interviewees, by establishing trust and identification-based ties with the interviewers (peer interviewing); and (iii) to gain access to social networks which would normally be off-limits to academics and cisgender people.

Using the non-systematic "snowball" method, the interviewers mobilized their social networks and approached social groups as diverse as urban middle class university students and teachers, trans movement activists, people from urban peripheries and favelas, and people living in shelters, brothels 
or on the street. Enrollment criteria were: self-identification as part of the trans/travesti universe (thus excluding cisgender people), and being 18 years old or more. A total of 391 questionnaires was filled between December 2016 and September 2017.

\section{Self-attributed and aggregate gender identity categories}

The way researchers categorize gender identities outside the binary gender-sex system is not only an important theoretical issue for the social sciences, but also strategic for understanding people's access to citizen rights and health services 5 . Reviews of sociodemographic studies in this field 6,7 have depicted the complexity of expressions used to define and endorse gender identifications, and the limits of socially or clinically validated categories.

Recent epidemiological, sociological, and demographic surveys in European countries, the USA, Brazil, and other Latin-American countries have employed different strategies for dealing with gender identification. The main question has been whether to offer gender identity categories as a priori constructs (i.e., propose them as questions with fixed answers $8,9,10,11,12,13,14,15$ ) or as open-ended questions, so participants can provide their own definitions. In order to account for unique modes of subjective construction and apprehend this universe's diversity, the second option was chosen in Brazil, as well as in France 4 and other European countries 16 where the questionnaire was applied. The open-ended self-identification question was formulated as follows: "In regard to your gender identity and gender expression, how do you define yourself?".

Responses to this question, which have to be considered provisional and produced in a specific interviewing context, revealed a great variety of gender identity categories, as well as modes of political, scientific, media or commonsense discourse incorporation. Thus, although the gender identity categories most frequently evoked were those most commonly found in the Brazilian LGBT milieu, such as "travesti" ( $\mathrm{n}=93)$, "trans woman" ( $\mathrm{n}=41)$, and "trans man" $(\mathrm{n}=40)$, a considerable number of people identified themselves simply as "woman" $(n=25)$ or "man" $(n=53)$. Particularly striking were the more colloquial or even pejorative references to gender identity, such as "trava" $(n=20)$. Moreover, interviewees also referred to sets of gender identity categories which embodied either a critique of the man-woman opposition - as in "neither man nor woman" $(\mathrm{n}=1)$ and "trans non-binary person" $(n=1)$ - or a refusal to define themselves in identity terms - as in "discovering myself" $(n=1)$. Altogether, respondents provided 78 distinct formulations of gender-related terms and categories.

The multiplicity of gender self-identification processes warrants deeper analysis, particularly of the qualitative type. Nevertheless, the application of the quantitative data treatment proposed in this article to such a large number of categories would be impracticable. Thus, in a procedure previously adopted by other researchers 17 , these were grouped into six broader "aggregate gender identity categories". It is important to note that the analytic elaboration of these categories is not intended to gloss over respondents' modes of self-identification. On the contrary, they were based on these very modes of gender self-identification, and thus strike a compromise between research interests and how interviewees construe themselves subjectively.

The six aggregate gender identity categories were: man, trans man, woman, trans woman, travesti and non-binary (hereafter always in italics). It was considered important, in the first place, to separate gender identity expressions that made no reference to a trans identity or any kind of gender transition, but rather emphasized the two conventional sex/gender categories (man and woman) 18. Accordingly, respondents who employed these expressions to identify themselves, even if accompanied by some kind of qualification, such as "man who has come to terms with himself", were subsumed as man $(\mathrm{n}=57)$ or woman $(\mathrm{n}=28)$.

Cases in which gender self-identification referred to transsexuality or some kind of gender transit as in "heterosexual transsexual woman" or "trans-masculine" - were subsumed as trans woman ( $\mathrm{n}=69)$ or trans man $(\mathrm{n}=59)$. Given the political and cultural specificity of travesti identities in Brazil 19,20,21,22, they were not included in the trans woman category. Thus, respondents whose gender self-identification mobilized some reference to the travesti universe, such as "trava", "travesti woman", "cdzinha" or simply "travesti", were classified as travestis $(\mathrm{n}=145)$. It is worth noting the use of the term "cdzinha" (literally "little cross-dresser"), also found in other studies 23 , as a way of referring to travestis who are at the beginning of their gender affirmation process. 
Lastly, a small number of respondents $(\mathrm{n}=14)$ alluded to the possibility of situating themselves outside a gender dichotomy, whether by referring to the emerging political identity of non-binary people, such as "trans non-binary person" or "queer non-binary", or using other ways of presenting themselves, such as "neither man, nor woman" or "gender fluid". In all these cases, they were referred to using the non-binary aggregate gender identity category. Thus, even when these formulations also evoked terms such as "trans", "man" or "woman", they were subsumed as non-binary. This choice is justified by the emergence of non-binary people (seeking to differentiate themselves from travestis and trans people) as political actors in the contemporary Brazilian gender diversity arena 20,24.

Construction of these aggregate gender identity categories also involved certain expectations as to the respondents' sociodemographic profiles, their access to legal services, and their health itineraries. According to the methodological procedure described above, woman was separated from trans woman, and man from trans man, on the hypothesis that respondents whose self-identification did not use expressions referring to gender transits were declaring that they had reached the end of their health itinerary, and had concluded their gender affirmation process. This expectation was based on ethnographic observations regarding some transsexual men who "reject the term 'transsexual' because they see transsexuality as something transitory which will be surmounted by access to medical/surgical technologies and legal recognition" 24 (p. 518). In a sense, these analytical categories replace others that are much more culturally and politically insensitive, such as FtM (Female to Male) or MtF (Male to Female), commonly used in surveys applied to this population.

As will be shown below, independently of whether or not these expectations are fulfilled, aggregate gender identity categories were in fact useful as means for understanding, through descriptive analysis, the diversity of itineraries followed by the interviewees, and for revealing important sociological differences between them.

\section{Respondents' sociodemographic profiles}

Regarding general sociodemographic data, our sample was composed mainly of young people, with $76.7 \%$ of respondents aged between 18 and 34. The majority (68.3\%) identified themselves as "preto" (black) or "pardo" (brown), official census categories specified by the Brazilian Institute of Geography and Statistics (IBGE) 25. Most of them lived in the city of Rio de Janeiro (59.1\%) or its metropolitan region $(39.1 \%)$.

The percentage of young and black/brown people in our sample was considerably higher than Rio de Janeiro's average. In our sample, $47.8 \%$ of the interviewees were $25-34$ years old, whereas this age group corresponded to only $17 \%$ of the population of the Rio de Janeiro municipality during the last census (2010) 25. Meanwhile, the number of interviewees over 45 years old $(\mathrm{n}=21)$ was conspicuously small. As regards color/racial identification, while $48 \%$ of the municipality's population is black/ brown, these groups represented $68.3 \%$ of our sample.

The interviewees' level of education was relatively low, with $32.2 \%$ having more than 9 and less than 12 years of schooling (complete elementary and incomplete middle school). In 2010, 16.8\% of Rio de Janeiro's population aged over 25 years had this level of education. Also, $15.6 \%$ of the interviewees had incomplete undergraduate education, likely indicating that they were university students.

Still according to the IBGE 26, the majority of respondents (65.2\%) earned up to three minimum wages (approximately USD 780), below the 2016 average monthly wage in the state of Rio de Janeiro (approximately USD 1,070) (Table 1).

This overall sociodemographic profile varied considerably according to the different aggregate gender identity categories. Travestis, for instance, constituted a rather exceptional group in terms of self-reported color/race: $72.4 \%$ considered themselves black (in sharp contrast to only $15.3 \%$ black trans men). Travestis tended to be in the lowest salary and education brackets: $42.8 \%$ earned up to $1 \mathrm{~min}-$ imum wage, and $26.9 \%$ had not completed elementary education. Although fewer in number $(n=14)$, non-binary people tended to be much younger than other aggregate gender identity categories (13 non-binary people were under 34 years old) and to have a higher level of education ( 8 held or were completing an undergraduate degree).

There were also important sociodemographic differences between men and trans men, and women and trans women. More men (50.9\%) than trans men (33.9\%) declared themselves black or brown; men 
Sociodemographic characteristics.

\begin{tabular}{|c|c|c|c|c|c|c|c|c|}
\hline & \multicolumn{8}{|c|}{ Aggregated identity categories } \\
\hline & \multirow{2}{*}{$\begin{array}{l}\text { Men } \\
\%(n)\end{array}$} & \multirow{2}{*}{$\begin{array}{c}\text { Trans men } \\
\text { \% (n) }\end{array}$} & \multirow{2}{*}{$\begin{array}{l}\text { Women } \\
\% \text { (n) }\end{array}$} & \multirow{2}{*}{$\begin{array}{c}\text { Trans women } \\
\text { \% (n) }\end{array}$} & \multirow{2}{*}{$\begin{array}{c}\text { Travestis } \\
\text { \% (n) }\end{array}$} & \multirow{2}{*}{$\begin{array}{l}\text { Non-binary } \\
\quad \%(n)\end{array}$} & \multirow{2}{*}{$\begin{array}{c}\text { Does not know/ } \\
\text { Did not answer } \\
\quad \%(n)\end{array}$} & \multirow{2}{*}{$\begin{array}{l}\text { Total } \\
\%(n)\end{array}$} \\
\hline & & & & & & & & \\
\hline Total & $14.6(57)$ & $15.1(59)$ & $7.2(28)$ & $17.6(69)$ & $37.1(145)$ & $3.6(14)$ & $4.9(19)$ & $100.0(391)$ \\
\hline \multicolumn{9}{|l|}{ Age (years) } \\
\hline $18-24$ & $24.6(14)$ & $37.3(22)$ & $17.9(5)$ & $21.7(15)$ & $30.3(44)$ & $57.1(8)$ & $26.3(5)$ & 28.9 (113) \\
\hline $25-34$ & $52.6(30)$ & $45.8(27)$ & $39.3(11)$ & $44.9(31)$ & $49.7(72)$ & $35.7(5)$ & $57.9(11)$ & 47.8 (187) \\
\hline $35-39$ & $10.5(6)$ & $5.1(3)$ & $14.3(4)$ & $21.7(15)$ & $13.8(20)$ & $0.0(0)$ & $15.8(3)$ & $13.0(51)$ \\
\hline $39-45$ & $5.3(3)$ & $5.1(3)$ & $7.1(2)$ & $4.3(3)$ & $2.1(3)$ & $7.1(1)$ & $0.0(0)$ & $3.8(15)$ \\
\hline $\begin{array}{l}\text { Does not know/Did not } \\
\text { answer }\end{array}$ & $0.0(0)$ & $0.0(0)$ & $3.6(1)$ & $1.4(1)$ & $1.4(2)$ & $0.0(0)$ & $0.0(0)$ & $1.0(4)$ \\
\hline Total & $100.0(57)$ & $100.0(59)$ & $100.0(28)$ & $100.0(69)$ & $100.0(145)$ & $100.0(14)$ & $100.0(19)$ & $100.0(391)$ \\
\hline \multicolumn{9}{|l|}{ Skin color } \\
\hline Black & $21.1(12)$ & $15.3(9)$ & $25.0(7)$ & $53.6(37)$ & $72.4(105)$ & $7.1(1)$ & $42.1(8)$ & 45.8 (179) \\
\hline Brown & $29.8(17)$ & $18.6(11)$ & $42.9(12)$ & $15.9(11)$ & $17.2(25)$ & $42.9(6)$ & $31.6(6)$ & $22.5(88)$ \\
\hline White & $42.1(24)$ & $64.4(38)$ & $25.0(7)$ & $26.1(18)$ & $5.5(8)$ & $35.7(5)$ & $10.5(2)$ & $26.1(102)$ \\
\hline Yellow & $1.8(1)$ & $1.7(1)$ & $0.0(0)$ & $4.3(3)$ & $1.4(2)$ & $0.0(0)$ & $0.0(0)$ & $1.8(7)$ \\
\hline Indigenous & $3.5(2)$ & $0.0(0)$ & $7.1(2)$ & $0.0(0)$ & $0.7(1)$ & $7.1(1)$ & $0.0(0)$ & $1.5(6)$ \\
\hline Did not answer & $1.8(1)$ & $0.0(0)$ & $0.0(0)$ & $0.0(0)$ & $2.8(4)$ & $7.1(1)$ & $15.8(3)$ & $2.3(9)$ \\
\hline Total & $100.0(57)$ & $100.0(59)$ & $100.0(28)$ & $100.0(69)$ & $100.0(145)$ & $100.0(14)$ & $100.0(19)$ & $100.0(391)$ \\
\hline \multicolumn{9}{|l|}{ Current residence } \\
\hline Rio de Janeiro-capital & $49.1(28)$ & $52.5(31)$ & $67.9(19)$ & $71.0(49)$ & $51.7(75)$ & $71.4(10)$ & $100.0(19)$ & $59.1(231)$ \\
\hline $\begin{array}{l}\text { Rio de Janeiro-metropolitan } \\
\text { area }\end{array}$ & $47.4(27)$ & $42.4(25)$ & $32.1(9)$ & $27.5(19)$ & $47.6(69)$ & $28.6(4)$ & $0.0(0)$ & $39.1(153)$ \\
\hline $\begin{array}{l}\text { Does not know/Did not } \\
\text { answer }\end{array}$ & $0.0(0)$ & $0.0(0)$ & $0.0(0)$ & $0.0(0)$ & $0.7(1)$ & $0.0(0)$ & $0.0(0)$ & $0.3(1)$ \\
\hline Total & $100.0(57)$ & $100.0(59)$ & $100.0(28)$ & $100.0(69)$ & $100.0(145)$ & $100.0(14)$ & $100.0(19)$ & $100.0(391)$ \\
\hline \multicolumn{9}{|l|}{ Level of education } \\
\hline $\begin{array}{l}\text { Incomplete elementary } \\
\text { education }\end{array}$ & $3.5(2)$ & $0.0(0)$ & $21.4(6)$ & $17.4(12)$ & $26.9(39)$ & $0.0(0)$ & $26.3(5)$ & $16.4(64)$ \\
\hline $\begin{array}{l}\text { Complete elementary } \\
\text { education }\end{array}$ & $1.8(1)$ & $0.0(0)$ & $7.1(2)$ & $14.5(10)$ & $31.0(45)$ & $0.0(0)$ & $15.8(3)$ & $15.6(61)$ \\
\hline Incomplete middle education & $15.8(9)$ & $6.8(4)$ & $3.6(1)$ & $11.6(8)$ & $26.2(38)$ & $7.1(1)$ & $21.1(4)$ & $16.6(65)$ \\
\hline Complete middle education & $22.8(13)$ & $30.5(18)$ & $21.4(6)$ & $15.9(11)$ & $6.9(10)$ & $28.6(4)$ & $26.3(5)$ & $17.1(67)$ \\
\hline Technical level & $10.5(6)$ & $8.5(5)$ & $0.0(0)$ & $2.9(2)$ & $3.4(5)$ & $7.1(1)$ & $5.3(1)$ & $5.1(20)$ \\
\hline Incomplete higher education & $26.3(15)$ & $33.9(20)$ & $21.4(6)$ & $15.9(11)$ & $2.8(4)$ & $35.7(5)$ & $0.0(0)$ & $15.6(61)$ \\
\hline $\begin{array}{l}\text { Does not know/Did not } \\
\text { answer }\end{array}$ & $0.0(0)$ & $0.0(0)$ & $0.0(0)$ & $2.9(2)$ & $1.4(2)$ & $0.0(0)$ & $0.0(0)$ & $1.0(4)$ \\
\hline Total & $100.0(57)$ & $100.0(59)$ & $100.0(28)$ & $100.0(69)$ & $100.0(145)$ & $100.0(14)$ & $100.0(19)$ & $100.0(391)$ \\
\hline \multicolumn{9}{|l|}{ Income (minimum wage) } \\
\hline Up to 1 & $28.1(16)$ & $27.1(16)$ & $25.0(7)$ & $24.6(17)$ & $42.8(62)$ & $21.4(3)$ & $10.5(2)$ & $31.5(123)$ \\
\hline $1-2$ & $26.3(15)$ & $27.1(16)$ & $17.9(5)$ & $27.5(19)$ & $33.1(48)$ & $42.9(6)$ & $5.3(1)$ & $28.1(110)$ \\
\hline $2-3$ & $12.3(7)$ & $5.1(3)$ & $17.9(5)$ & $5.8(4)$ & $0.7(1)$ & $14.3(2)$ & $0.0(0)$ & $5.6(22)$ \\
\hline $3-5$ & $5.3(3)$ & $3.4(2)$ & $0.0(0)$ & $10.1(7)$ & $0.0(0)$ & $0.0(0)$ & $5.3(1)$ & $3.3(13)$ \\
\hline $\begin{array}{l}\text { Does not know/Did not } \\
\text { answer }\end{array}$ & $3.5(2)$ & $5.1(3)$ & $3.6(1)$ & $5.8(4)$ & $2.8(4)$ & $7.1(1)$ & $10.5(2)$ & $4.3(17)$ \\
\hline Unknown & $19.3(11)$ & $27.1(16)$ & $32.1(9)$ & $18.8(13)$ & $20.0(29)$ & $14.3(2)$ & $68.4(13)$ & $23.8(93)$ \\
\hline Total & $100.0(57)$ & $100.0(59)$ & $100.0(28)$ & $100.0(69)$ & $100.0(145)$ & $100.0(14)$ & $100.0(19)$ & $100.0(391)$ \\
\hline
\end{tabular}


were also poorer and had lower levels of schooling. The differences between women and trans women were not so noticeable: $69.5 \%$ of the former declared themselves black or brown, against $67.9 \%$ of the latter. Considering men and trans men on the one hand and women and trans women on the other, only $42.2 \%$ of the former declared themselves black or brown, compared to $69 \%$ of the latter.

It must be stressed once again that our sample was constructed from the interviewers' social networks and using the non-systematic "snowball" method, which generally leads to a sample with sociodemographic profiles similar to the interviewers. Nevertheless, efforts were made to reach groups not usually included in studies in this area, thus encompassing a greater diversity. Even so, the sociodemographic profiles identified were similar to those found by surveys of trans women and travestis in Brazil 2.

\section{Body modification: hormonization and surgeries}

It is crucial to emphasize that Brazilian Unified National Health System (SUS), as part of its "Transsexualization Process”, provides access to hormones and body modification surgery for gender affirmation - as do private health services 2,27,28,29. This is crucial information for the analysis of the health itineraries of trans people and travestis in Brazil (Table 2).

Hormones are generally the first body modification technology used by transsexual men, for whom this tends to be more important than genital reassignment surgery. In our sample, due to their particular health itineraries and the enormous difficulty of obtaining testosterone without a prescription, $57.9 \%$ of men and $50.8 \%$ of trans men took hormones via doctor's prescription.

As measured by a multiple response question, only a few men and trans men interviewed had access to hormones through gyms (5.3\% of men and 5.1\% of trans men) and veterinary sources (1.8\% of men and $1.7 \%$ of trans men). These are usual 30,31, although illegal, ways of obtaining them in Brazil. Another source for hormones was other people who also used them (14\% of men and $20.3 \%$ of trans men).

By contrast, most women (50\%), trans women (53.6\%) and especially travestis (67.6\%) had access to hormones through unofficial channels, and had started hormone treatment of their own accord. It should be highlighted that only $2.1 \%$ of travestis acquired hormones via doctor's prescription. Most acquired them from other trans or travestis who also used them (66.9\%) or by exposing themselves to even more unsafe alternatives. For example, while $24.8 \%$ of travestis purchased hormones online, only $7.1 \%$ of women and $7.2 \%$ of trans women adopted the same procedure, thus incurring a lower risk of consuming counterfeit products.

We agree with other researchers 32 that it is crucial to criticize individualizing discourses that blame trans people and travestis for illnesses resulting from excessive self-administered use of hormones (or even industrial silicone): after all, this health itinerary reflects a social context marked by stigmatization and discrimination processes 33,34. This can also be seen in healthcare personnel's lack of training for dealing with transexuality 21, and other more structural obstacles to hormone access 2.

Among all the different means of gaining access to hormones, healthcare institutions were one of the least mentioned by interviewees: $3.5 \%$ of men, $5.1 \%$ of trans men, $1.4 \%$ of travestis and none of the women and trans women declared that they accessed hormones through such services. All in all, only $1.8 \%$ of the sample obtained access to hormones through health institutions (Table 3 ).

For trans people and travestis, surgical procedures are a crucial element in constructing a gendered body 35,36 . Interviewees seemed to prioritize procedures involving the "external" and more visible surface of their body, such as masculinizing mammoplasty, over those that could be considered "internal" and not immediately visible, such as hysterectomy or orchiectomy. This prioritization may be linked to the fact that, in addition to being less complex, these medical procedures create visible body markers that are essential for the social recognition of an embodied gendered experience.

"External" surgical procedures generally returned much higher "already done" scores than "internal” ones. By and large, "already done" responses were less frequent among travestis than among women and trans women, although it cannot be inferred that these surgeries are less important to travestis. These response scores should be interpreted in view of the fact that travestis are generally the group most exposed to risks and experiences of vulnerability, in various social contexts. This includes difficulties in accessing the very healthcare services through which they could undergo this kind of intervention. 
Hormonization.

\begin{tabular}{|c|c|c|c|c|c|c|c|c|}
\hline & Men & Trans men & Women & Trans women & Travestis & Non binary & $\begin{array}{c}\text { Does not know/Did } \\
\text { not answer }\end{array}$ & Total \\
\hline & $\%(n)$ & $\%(n)$ & $\%(n)$ & $\%(n)$ & $\%(n)$ & $\%(n)$ & $\%(n)$ & $\%(n)$ \\
\hline Total & $14.6(57)$ & $15.1(59)$ & $7.2(28)$ & $17.6(69)$ & $37.1(145)$ & $3.6(14)$ & 4.9 (19) & $100.0(391)$ \\
\hline \multicolumn{9}{|l|}{ Use of hormones } \\
\hline $\begin{array}{l}\text { Yes without } \\
\text { prescription }\end{array}$ & $28.1(16)$ & $30.5(18)$ & $50.0(14)$ & $53.6(37)$ & $67.6(98)$ & $21.4(3)$ & $15.8(3)$ & $48.3(189)$ \\
\hline Yes with prescription & $57.9(33)$ & $50.8(30)$ & $42.9(12)$ & $23.2(16)$ & $2.1(3)$ & $21.4(3)$ & $15.8(3)$ & $25.6(100)$ \\
\hline No hormones & $0.0(0)$ & $0.0(0)$ & $3.6(1)$ & $7.2(5)$ & $3.4(5)$ & $14.3(2)$ & $47.4(9)$ & $5.6(22)$ \\
\hline $\begin{array}{l}\text { Does not know/Did } \\
\text { not answer }\end{array}$ & $0.0(0)$ & $1.7(1)$ & $0.0(0)$ & $4.3(3)$ & $14.5(21)$ & $0.0(0)$ & $0.0(0)$ & $6.4(25)$ \\
\hline Total & $100.0(57)$ & $100.0(59)$ & $100.0(28)$ & $100.0(69)$ & $100.0(145)$ & $100.0(14)$ & $100.0(19)$ & $100.0(391)$ \\
\hline \multicolumn{9}{|l|}{$\begin{array}{l}\text { Acquisition of } \\
\text { hormones: } \\
\text { How did you acquire } \\
\text { hormones? } \\
\text { Other trans people who } \\
\text { also used them }\end{array}$} \\
\hline No & $80.7(46)$ & $76.3(45)$ & $64.3(18)$ & $56.5(39)$ & $27.6(40)$ & $71.4(10)$ & $94.7(18)$ & $55.2(216)$ \\
\hline $\begin{array}{l}\text { Does not know/Did } \\
\text { not answer }\end{array}$ & $5.3(3)$ & $3.4(2)$ & $14.3(4)$ & $11.6(8)$ & $5.5(8)$ & $0.0(0)$ & $0.0(0)$ & $6.4(25)$ \\
\hline Total & $100.0(57)$ & $100.0(59)$ & $100.0(28)$ & $100.0(69)$ & $100.0(145)$ & $100.0(14)$ & $100.0(19)$ & $100.0(391)$ \\
\hline \multicolumn{9}{|l|}{ Institution/Drugstore } \\
\hline with prescription & & & & & & & & \\
\hline No/No & $38.6(22)$ & $45.8(27)$ & $53.6(15)$ & $73.9(51)$ & $91.7(133)$ & $78.6(11)$ & $89.5(17)$ & $70.6(276)$ \\
\hline No/Yes & $52.6(30)$ & $45.8(27)$ & $32.1(9)$ & $14.5(10)$ & $1.4(2)$ & $21.4(3)$ & $10.5(2)$ & $21.2(83)$ \\
\hline Yes/No & $1.8(1)$ & $3.4(2)$ & $0.0(0)$ & $0.0(0)$ & $0.0(0)$ & $0.0(0)$ & $0.0(0)$ & $0.8(3)$ \\
\hline $\begin{array}{l}\text { Does not know/Did } \\
\text { not answer }\end{array}$ & $5.3(3)$ & $3.4(2)$ & $14.3(4)$ & $11.6(8)$ & $5.5(8)$ & $0.0(0)$ & $0.0(0)$ & $6.4(25)$ \\
\hline Total & $100.0(57)$ & $100.0(59)$ & $100.0(28)$ & $100.0(69)$ & $100.0(145)$ & $100.0(14)$ & 100.0 (19) & 100.0 (391) \\
\hline
\end{tabular}

All men and trans men interviewed reported that they had already undergone or were considering masculinizing mammoplasty. There appears to be no notable difference between men and trans men in this case: among the former, $24.6 \%$ had had the operation and $75.4 \%$ expressed the wish to have it performed in the future, while percentages for the latter were $28.8 \%$ and $71.2 \%$, respectively. These numbers show how crucial this procedure is considered for the construction of a masculine body, and for the experience of being masculine 30 . Note that it was only in 2010 that Brazil's Federal Medical Council considered 27,28 that trans men surgical procedures such as masculinizing mammoplasty and hysterectomy were no longer experimental, and authorized them to be performed at any public or private hospital. Neophalloplasty is still considered experimental, supposedly due to the new organ's functional limitations. In 2013, the Brazilian Ministry of Health included trans men in the SUS Transsexualization Process 29.

Among interviewees who were considering masculinizing mammoplasty, $32.8 \%$ failed to perform the procedure for lack of funds, while $24.1 \%$ were in the Transsexualization Process queue. Although this public policy is an important instrument for guaranteeing this population's rights, $64.5 \%$ of men and trans men who underwent the procedure did so in private Brazilian clinics - perhaps because they had only recently been included in the SUS Process. Among those who underwent the procedure in 
Table 3

Surgeries.

\begin{tabular}{|c|c|c|c|c|}
\hline Masculine & & $\begin{array}{l}\text { Men } \\
\%(n)\end{array}$ & $\begin{array}{c}\text { Trans men } \\
\%(n)\end{array}$ & $\begin{array}{l}\text { Total } \\
\%(n)\end{array}$ \\
\hline \multicolumn{5}{|l|}{ Masculinizing mammoplasty } \\
\hline Already done & & $24.6(14)$ & $28.8(17)$ & $26.7(31)$ \\
\hline Consider undergoing & & $75.4(43)$ & $71.2(42)$ & $73.3(85)$ \\
\hline Total & & $100.0(57)$ & $100.0(59)$ & $100.0(116)$ \\
\hline \multicolumn{5}{|l|}{ Oophorectomy and/or hysterectomy } \\
\hline Already done & & $8.8(5)$ & $11.9(7)$ & $10.3(12)$ \\
\hline Does not know/Did not answer & & $1.8(1)$ & $0.0(0)$ & $0.9(1)$ \\
\hline Total & & $100.0(57)$ & $100.0(59)$ & $100.0(116)$ \\
\hline \multicolumn{5}{|c|}{ Clitoral enlargement, urethral extension and scrotum construction } \\
\hline Already done & & $1.8(1)$ & $0.0(0)$ & $0.9(1)$ \\
\hline Does not know/Did not answer & & $0.0(0)$ & $5.1(3)$ & $2.6(3)$ \\
\hline Total & & $100.0(57)$ & $100.0(59)$ & $100.0(116)$ \\
\hline \multicolumn{5}{|l|}{ Neophalloplasty } \\
\hline Does not know/Did not answer & & $0.0(0)$ & $3.4(2)$ & $1.7(2)$ \\
\hline Does not apply & & $1.8(1)$ & $1.7(1)$ & $1.7(2)$ \\
\hline Total & & $100.0(57)$ & $100.0(59)$ & $100.0(116)$ \\
\hline \multirow[t]{2}{*}{ Feminine } & Women & Trans women & Travestis & Total \\
\hline & $\%(n)$ & $\%(n)$ & $\%(n)$ & $\%(n)$ \\
\hline \multicolumn{5}{|l|}{ Orchiectomy } \\
\hline Already done & $7.1(2)$ & $5.8(4)$ & $1.4(2)$ & $3.3(8)$ \\
\hline Does not know/Did not answer & $7.1(2)$ & $2.9(2)$ & $2.1(3)$ & $2.9(7)$ \\
\hline Does not apply & $10.7(3)$ & $14.5(10)$ & $14.5(21)$ & $14.0(34)$ \\
\hline Total & $100.0(28)$ & $100.0(69)$ & $100.0(145)$ & $100.0(242)$ \\
\hline \multicolumn{5}{|l|}{ Vaginoplasty } \\
\hline Already done & $14.3(4)$ & $4.3(3)$ & $0.0(0)$ & $2.9(7)$ \\
\hline Does not apply & $7.1(2)$ & $4.3(3)$ & $8.3(12)$ & $7.0(17)$ \\
\hline Total & $100.0(28)$ & $100.0(69)$ & $100.0(145)$ & $100.0(242)$ \\
\hline \multicolumn{5}{|l|}{ Laryngoplasty } \\
\hline Already done & $7.1(2)$ & $4.3(3)$ & $0.7(1)$ & $2.5(6)$ \\
\hline Does not know/Did not answer & $10.7(3)$ & $1.4(1)$ & $2.8(4)$ & $3.3(8)$ \\
\hline Does not apply & $17.9(5)$ & $8.7(6)$ & $10.3(15)$ & $10.7(26)$ \\
\hline Total & $100.0(28)$ & $100.0(69)$ & $100.0(145)$ & $100.0(242)$ \\
\hline \multicolumn{5}{|l|}{ Silicone prostheses } \\
\hline Already done & $17.9(5)$ & $30.4(21)$ & $28.3(41)$ & $27.7(67)$ \\
\hline Does not know/Did not answer & $7.1(2)$ & $1.4(1)$ & $1.4(2)$ & $2.1(5)$ \\
\hline Does not apply & $0.0(0)$ & $11.6(8)$ & $13.8(20)$ & $11.6(28)$ \\
\hline Total & $100.0(28)$ & $100.0(69)$ & $100.0(145)$ & $100.0(242)$ \\
\hline
\end{tabular}

public hospitals, $19.4 \%$ did so through the Transsexualization Process, while $6.5 \%$ were not registered in the program.

Only one interviewee reported having clitoral enlargement, urethral extension and neoscrotum surgical construction. However, most (71.9\% of men and $61 \%$ of trans men) responded that they were thinking of having these procedures performed. Also worthy of note is the fact that a considerable number of individuals (31\%) declared that they had not undergone such procedures because they did not trust current surgical techniques. 
A similar result was seen in the case of neophalloplasty, with $35.1 \%$ of interviewees expressing their distrust. Also, 33.3\% of men and 35.6\% of trans men answered that they were not considering this procedure, and none declared having already undergone it. However, $64.9 \%$ of men and $59.3 \%$ of trans men said that they were considering it.

A large number of participants said that they were considering oophorectomy and/or hysterectomy ( $86 \%$ of men and $81.4 \%$ of trans men). Only $8.8 \%$ men and $11.9 \%$ trans men had already undergone these procedures.

Among women, only $14.3 \%$ declared that they had had vaginoplasty, and the percentage was even lower among trans women (4.3\%). A larger percentage of trans women (42\%) than women (21.4\%) declared that they had not undergone this procedure, and were not considering doing so. Meanwhile, none of the travestis responded that they had had vaginoplasty, and $53.8 \%$ declared they were not considering it. However, $35.2 \%$ said they were considering a vaginoplasty. The higher proportion of trans women and travestis who said that they were not considering vaginoplasty is meaningful, not only due to showing that gender is not defined by the genitals $4,34,37$, but also because it helps understand the health itineraries of these trans women and travestis.

Numbers for participants who asserted that they had undergone laryngoplasty were also small: only $7.1 \%$ women and $4.3 \%$ trans women. Among women, the percentages of those who intended to undergo this procedure and those who did not were similar (35.7\% and $28.6 \%$, respectively). There was a slightly more evident difference when observing the data regarding trans women's desire to undergo this procedure, with $49.6 \%$ saying they were considering it, and $36.2 \%$ saying they were not. Only 1 travesti $(0.7 \%)$ said she had undergone this procedure, while $35.9 \%$ said they were considering it, and $50.3 \%$ said they were not.

Regarding the placement of silicone prostheses, many trans women (30.4\%) responded that they had undergone the procedure, a higher percentage when compared to women's (17.9\%). On the other hand, a smaller number of trans women (34.8\%) than women $(71.4 \%)$ said they intended to undergo the placement of silicone prostheses. While only $3.6 \%$ of women were not considering doing so, the percentage rose to $21.7 \%$ among trans women. In the case of travestis, only $24.8 \%$ said that they did not have prostheses implanted and were not considering the procedure. Meanwhile, 28.3\% travestis had silicone prostheses implanted, and $31.7 \%$ were considering implanting them.

As an alternative to implanting silicone prostheses, a relatively high percentage (46.7\%) of all women, trans women and travestis had used liquid silicone. Use of liquid silicone was more widespread among travestis, $55.6 \%$ of whom had undergone this procedure, compared to $31.8 \%$ of trans women and $25 \%$ of women. Similar results were found by other studies 2 .

Facial feminization plastic surgery procedures were a prospect for more women than trans women and travestis: $53.6 \%$ of women, $46.4 \%$ of trans women and $46.2 \%$ of travestis were considering this type of procedure.

A small number of women and trans women ( $7.1 \%$ and $5.8 \%$, respectively) declared that they had undergone orchiectomy, while $50 \%$ of women and $38 \%$ of trans women said they were considering it. However, $25 \%$ of women and $42 \%$ of trans women indicated that they had not undergone the procedure and were not considering doing so. Most travestis (53.8\%) declared they had neither undergone nor intended to undergo orchiectomy, and $1.4 \%$ of interviewees ( 2 people in a universe of 145 interviewees) declared that they had already undergone the procedure, while $28.3 \%$ said they were considering it.

Those who classified themselves as non-binary also had gender body modification expectations: 10 of the 14 non-binary people interviewed said that they were considering masculinizing mammoplasty, and 7 said they were considering clitoral enlargement, urethral extension, neoscrotum construction, and phalloplasty. In this group, one person reported considering silicone implants.

\section{Access to healthcare services and health itineraries}

There were some important differences in the ways interviewees accessed healthcare services. For female breast construction surgery, $42.1 \%$ of women, trans women and travestis who had undergone the procedure resorted to private Brazilian clinics. Only 5.3\% used public healthcare services $(3.5 \%$ within the Transsexualization Process, and 1.8\% outside that program). Much higher percentages of 
men and trans men underwent equivalent procedures in public healthcare services: $19.4 \%$ did so within the program, and $6.5 \%$ outside of it.

Also, whereas none of the men, trans men and women reported having undergone this procedure in clandestine clinics, $23.8 \%$ of trans women and $58.1 \%$ of travestis declared that their breast construction had been performed in such establishments.

Lack of funds to pay for hysterectomy and oophorectomy was also mentioned by $40.5 \%$ of the men and trans men combined group. Women, trans women and travestis were prevented, mainly by lack of funds, from undertaking procedures including vaginoplasty (35.4\%), orchiectomy (29.9\%), laryngoplasty (38\%), placement of silicone prostheses (35.4\%), and facial feminization surgeries (47.6\%), as confirmed by other studies 21. Complete information on the risks of the surgical interventions to which they were submitted was given to $80.6 \%$ of the men and trans men combined group, in contrast to $40.3 \%$ in the women, trans women and travestis combined group. There were also important differences within each combined group: $100 \%$ women reported that they had been fully informed, while only $50 \%$ trans women and $22 \%$ travestis declared the same.

The main professionals involved in post-operative monitoring are surgeons and general practitioners. Even though many procedures were performed by private healthcare services, the public healthcare system played an important role in post-operative monitoring, occurring in $45 \%$ of the cases in our sample. As observed by other authors 30 , the fact that trans people have funds to make use of private healthcare services does not mean that their difficulties in accessing healthcare have been overcome, given the deficiencies in the healthcare services provided to this population.

Aggregate gender identity categories differed in whether or not the gender affirmation process had been concluded. Numbers for categories who declared having concluded the process were: men (15.8\%), trans men (15.3\%), women (39.2\%), trans women (24.6\%), and travestis (23.4\%). These differences do not allow one to conclude that some categories were closer to ending the process than others; among women, trans women, and travestis, however, it was women who most often reported having concluded their gender affirmation process. The difference between men and trans men was not very pronounced; this is perhaps associated with the fact that in Brazil the social visibility of transsexual masculinity is a much more recent phenomenon. In any case, in both groups, the percentage of those who thought they had finished their gender affirmation process was not very high. This may be because they think the process is never-ending or because services are so scarce and precarious that they cannot fulfill their desires or, lastly, because the survey's format itself circumscribes the formulation of responses.

\section{Conclusions}

The data presented here reveal the different attitudes, practices and health itineraries related to body modification technologies as expressed by women, trans women, travestis, men, trans men, and nonbinary people.

The study also described the different forms of gender self-identification used by trans people and travestis, thus offering a statistical measure of the diversity of situations they find themselves in. However, in the absence of a benchmark travesti/transsexual population, it is difficult to assess the representativeness of our sample or the relative weight of the different self-identification categories constructed. We chose not to restrict participation in this study to people engaged in the Transsexualization Process. That choice may help explain why only a small number of participants accessed and used health services on a regular basis. Despite these limitations, and without claiming representativeness, this study provides additional detailed information on a population that usually does not access health services and hospitals, encompassing different groups and their diverse health itineraries.

At present, neither the public nor private healthcare system seem to provide a sufficient response to the needs of trans, travesti, and non-binary people. In the SUS, only five reference health centers offer the Transsexualization Process. Thus, it is necessary to highlight the chronic lack of services and professional care for the trans population in the public health system. The lack of such support exposes this community to the risk of illness due to the excessive, uncontrolled, and unmonitored 
use of hormones and body modifications. As a result, there is a growing demand for health policies to increase the visibility of these issues and afford them due attention, thus guaranteeing recognition for trans people's rights.

Thus, in addition to providing relevant information about the health itineraries of trans people and travestis (especially regarding hormonization procedures, access to surgeries, and the different possibilities of accessing health services), this article also offers input for policy making to strengthen health service networks for this population, considering the diversity of gender experiences it comprises.

The discussion on aggregate gender identity categories initiated here includes questioning to what extent and how these categories cut across the health itineraries of trans people, and opens up a series of avenues by which the endeavor to identify and better understand the complex ways trans people engage in different health production processes can be pursued. This survey thus presents data that can prompt a dialogue with other field studies, providing more information about people who identify themselves with trans masculinities and non-binarism - usually less addressed by surveys than trans femininities and travestilities. Moreover, the study's political and methodological choices can contribute to the theoretical and epistemological analysis of the public health and gender fields, by proposing an interrelation between quantitative studies, ethical and political concerns, and emergent developments in the trans and travesti universe.

\section{Contributors}

S. Carrara contributed to data analysis, establishment of analytical categories, and writing of the article. J. G. Hernandez contributed to the coordination of questionnaires' application, data collection, bibliographic review, and writing of the article. A. P. Uziel contributed to the overall coordination of the research, data analysis, proofreading and writing of the article. G. M. S. Conceição contributed in the statistical analysis of the research data. $\mathrm{H}$. Panjo contributed in the statistical analysis and preparation of research tables. A. C. O. Baldanzi contributed to bibliographic review and writing of the article. J. P. Queiroz contributed to ethnographic data analysis, bibliographic review, and writing of the article. L. B. D'Angelo contributed to data analysis, bibliographic review and writing of the article. A. M. S. Balthazar contributed to the coordination of questionnaires' application and data collection; analysis of sociodemographic data, and writing of the article. A. L. Silva Junior contributed to the coordination of questionnaires' application, data collection, bibliographic review, and writing of the article. A. Giami contributed in the overall coordination of the research and writing of the article.

\section{Additional Information}

ORCID: Sérgio Carrara (0000-0001-5165-3720); Jimena de Garay Hernandez (0000-0002-05641056); Anna Paula Uziel (0000-0001-7807-3910); Greice Maria Silva da Conceição (0000-0001-98404860); Henri Panjo (0000-0002-9172-3735); Ana Camilla de Oliveira Baldanzi (0000-0001-84385419); João Pedro Queiroz (0000-0001-8412-9108); Luisa Bertrami D’Angelo (0000-0001-5724-3511); Adriana Maria Shad e Balthazar (0000-0001-78821042); Aureliano Lopes da Silva Junior (0000-00029872-9830); Alain Giami (0000-0001-7639-3005).

\section{Acknowledgments}

The research is being developed with the support of National Agency for Recherche on AIDS and Hepatitis (Agence Nationale de Recherche sur le SIDA et les Hépatites - ANRS/France - Project ANRS n. 12343/2015) and the State University of Rio de Janeiro. Approved by the Brazilian National Ethics Research Committee, ruling number 1.688.709. 


\section{References}

1. Dourado I, Silva LAV, Magno L, Lopes M, Cerqueira C, Prates A, et al. Construindo pontes: a prática da interdisciplinaridade. Estudo PopTrans: um estudo com travestis e mulheres transexuais em Salvador, Bahia, Brasil. Cad Saúde Pública 2016; 32:e00180415.

2. Pinto T, Teixeira FB, Barros CRS, Martins RB, Saggese GSR, Barros DD, et al. Silicone líquido industrial para transformar o corpo: prevalência e fatores associados ao seu uso entre travestis e mulheres transexuais em São Paulo, Brasil. Cad Saúde Pública 2017; 33:e00113316.

3. Cabral A, Martinez-Hemáez A, Andrade E, Cherchiglia M. Itinerários terapêuticos: o estado da arte da produção científica no Brasil. Ciênc Saúde Colet 2011; 16:4433-42.

4. Giami A, Beaubatie E. Gender identification and sex reassignment surgery in the trans population: a survey study in France. Arch Sex Behav 2014; 43:1491-501.

5. Stryker S, Currah P. Introduction. TSQ: Transgender Studies Quarterly 2015; 2:1-18.

6. Meier SC, Labuski CM. The demographics of the transgender population. In: Baumle AK, editor. International handbook on the demography of sexuality. Dordrecht: Springer; 2013. p. 289-327.

7. Giami A. Compter les trans: enjeux politiques et épistémologiques. In: Meidani A, Alessandrin A, editors. Parcours de santé. Parcours de Genre. Toulouse: Presses Universitaires du Midi; 2018. pp.118-31. (Collection "Santé Société").

8. Motmans J, Biolley I, Debunne S. Être transgenre en Belgique. Un aperçu de la situation sociale et juridique des personnes transgenres. Bruxelles: Institut pour L'égalité des Femmes et des Hommes; 2009.

9. McNeil J, Bailey L, Ellis S, Morton J, Regan M. Trans mental health and emotional wellbeing study. Edinburgh: Scottish Transgender Alliance; 2012.

10. Grant JM, Mottet LA, Tanis J, Harrison J, Herman JL, Keisling M. Injustice at every turn: a report of the National Transgender Discrimination Survey. Washington DC: National Center for Transgender Equality and National Gay and Lesbian Task Force; 2011.

11. Brito A, Jiménez AS, Sívori H, Lacerda P, Glockner NL, Garza A. Política derechos, violencia y sexualidad. Encuesta Marcha del Orgullo y la Diversidad Sexual Ciudad de México - 2008. Rio de Janeiro: Centro de Estudos, Pesquisa e Desenvolvimento Tecnológico em Saúde Coletiva; 2012. (Coleção Documentos, 11).

12. Barrientos J, Díaz JL, Muñoz F. Derechos, política, violencia y diversidad sexual. Segunda Encuesta Marcha de la Diversidad Sexual Santiago de Chile 2011. Antofagasta: Universidad Católica del Norte/Movimiento por la Diversidad Sexual; 2012.
13. Carrara S, Aguião S, Lopes PVL, Tota M. Retratos da política LGBT no Estado do Rio de Janeiro. Rio de Janeiro: Centro de Estudos, Pesquisa e Desenvolvimento Tecnológico em Saúde Coletiva; 2017. (Coleção Documentos, 26).

14. Iosa T, Rabbia HH, Ruata MCS, Faúndes JMM, Vaggione JM. Política, sexualidades y derechos. Primera Encuesta. Marcha del orgullo y la diversidad Córdoba 2010. Rio de Janeiro: Centro de Estudos, Pesquisa e Desenvolvimento Tecnológico em Saúde Coletiva; 2012.

15. Carrara S, Ramos S, Facchini R, Simões J. Política, direitos, violência e homossexualidade. Pesquisa 9a Parada do Orgulho GLBT - São Paulo 2005. Rio de Janeiro: Centro de Estudos, Pesquisa e Desenvolvimento Tecnológico em Saúde Coletiva; 2006.

16. Vitelli R, Scandurra C, Pacifico R, Selvino M, Giami A. Trans identities and medical practice in Italy: self-positioning towards gender affirmation surgery. Sexologies 2017; 26:43-51.

17. Kuper LE, Nussbaum R, Mustanski B. Exploring the diversity of gender and sexual orientation identities in an online sample of transgender individuals. J Sex Res 2012; 49:244-54.

18. Bockting W. Transforming the paradigm of transgender health: a field in transition. Sexual and Relationship Therapy 2009; 24:103-7.

19. Simpson K. Transexualidade e travestilidade na saúde. In: Ministério da Saúde, organizador. Transexualidade e travestilidade na Saúde. Brasília: Ministério da Saúde; 2015. p. 9-15.

20. Carvalho M. "Travesti", "mulher transexual", "homem trans" e "não binário": interseccionalidades de classe e geração na produção de identidades políticas. Cadernos Pagu; 2018; (52): 185211.

21. Pelúcio L. Travestis, a (re)construção do feminino: gênero, corpo e sexualidade em um espaço ambíguo. Revista ANTHROPOLÓGICAS 2004; 15:123-54.

22. Sales A, Proença H, Peres WS. Expressões travestis: da precariedade aos gêneros nômades. In: Rodrigues A, Monzeli GA, Ferreira SRS, organizadores. A polícia no corpo: gêneros e sexualidades em disputa. Vitória: EDUFES; 2016. p. 47-64.

23. Amaral MS, Toneli MJF. Entre novatas, cdzinhas \& transformers: políticas de (re)existência na experiência de travestis iniciantes. História Agora: A Revista de História do Tempo Presente $2014 ; 15: 162-84$.

24. Almeida G. 'Homens trans': novos matizes na aquarela das masculinidades? Revista Estudos Feministas 2012; 20:513-23. 
25. Instituto Brasileiro de Geografia e Estatística. Censo Demográfico, 2010: características da população e dos domicílios: resultados do universo. https://biblioteca.ibge.gov.br/visua lizacao/periodicos/93/cd_2010_caracteristi cas_populacao_domicilios.pdf (accessed on 19/ Jun/2018).

26. Instituto Brasileiro de Geografia e Estatística. Brasil em síntese. https://cidades.ibge.gov.br/ brasil/rj/rio-de-janeiro/panorama (accessed on 19/Jun/2018).

27. Raimondi GA, Paulino DB, Teixeira FB. O que importa? As pesquisas brasileiras no campo da saúde e as (in)visibilidades das travestis e transexuais. Saúde Transform Soc 2016; 7:133-46.

28. Teixeira FB. (Des)engano: revisando as portarias do processo transexualizador no SUS. In: Uziel AP, Guilhon F, organizadores. Transdiversidades: práticas e diálogos em trânsitos. Rio de Janeiro: Eduerj; 2017. p. 313-52.

29. Ávila SN. FTM, transhomem, homem trans, trans, homem [Doctoral Dissertation]. Florianópolis: Universidade Federal de Santa Catarina; 2014.

30. Maranhão Filho E, Nery J. Trans-homens: a distopia nos tecno-homens. In: Ministério da Saúde, organizador. Transexualidade e travestilidade na Saúde. Brasília: Ministério da Saúde; 2015. p. 25-36.

31. Braz C, Souza E. Antropologia e políticas de saúde para homens trans no Brasil contemporâneo - diálogos entre duas pesquisas. In: 30a Reunião Brasileira de Antropologia. http:// evento.abant.org.br/rba/30rba/?id=19 (accessed on 19/Jun/2018).
32. Rocon P, Rodrigues A, Zamboni J, Pedrini M. Dificuldades vividas por pessoas trans no acesso ao Sistema Único de Saúde. Ciênc Saúde Colet $2016 ; 21: 2517-25$.

33. Costa A, Rosa Filho H, Pase PF, Fontanari AM, Catelan RF, Mueller A, et al. Healthcare need of and access barriers for Brazilian transgender and gender diverse people. J Immigr Minor Health 2018; 20:115-23.

34. Magno L, Dourado I, Silva LAV. Estigma e resistência entre travestis e mulheres transexuais em Salvador, Bahia, Brasil. Cad Saúde Pública 2018; 34:e00135917.

35. Bento B. Transviad@s: gênero, sexualidade e direitos humanos. Salvador: EDUFBA; 2017.

36. Halberstam J. Gaga feminism: sex, gender, and the end of normal (Queer Ideas/Queer Action). Boston: Beacon Press; 2013.

37. Murta D. Entre o "transexualismo verdadeiro" e a diversidade das experiências trans: uma discussão crítica sobre a produção da identidade transexual universal. In: Silva D, de Garay J, Lopes A, Uziel A, organizadores. Feminilidades: corpos e sexualidades em debate. Rio de Janeiro: Eduerj; 2013. p. 63-82. 


\section{Resumo}

O artigo examina os itinerários de saúde seguidos por travestis e mulheres e homens trans brasileiros na afirmação do seu próprio gênero, com base no inquérito Trans Uerj: Health and Citizenship of Trans People in Brazil. O inquérito teve como objetivos avaliar a diversidade e o perfil sociodemográfico da população trans/travesti e mapear as diversas maneiras pelas quais garantem seus direitos de cidadania, principalmente nos serviços saúde e em tecnologias de modificação do corpo. Os entrevistadores, majoritariamente pessoas trans e travestis, aplicaram 391 questionários na cidade e Região Metropolitana do Rio de Janeiro, com entrevistados/as de diferentes classes sociais, niveis de escolaridade e configurações de identidade de gênero, contatados através das redes sociais dos entrevistadores. A definição da identidade de gênero dos entrevistados usou um método original baseado nas autodefinições; as definições foram agregadas depois em seis categorias para fins de análise dos dados. $O$ artigo discute as múltiplas estratégias utilizadas pela população trans nos processos de afirmação de gênero para obter acesso ao uso regulado e/ou não regulado de hormônios e procedimentos cirúrgicos.

Pessoas Trans; Identidade de Gênero; Procedimentos de Redesignação de Gênero

\section{Resumen}

El artículo examina los itinerarios de salud seguidos por travestis brasileños, hombres trans y mujeres trans para la afirmación de su género, está basado en la encuesta Trans Uerj: Health and Citizenship of Trans People in Brazil. Los objetivos principales de esta encuesta fueron evaluar la diversidad de la población trans/travesti y su perfil sociodemográfico; así como mapear los diferentes caminos gracias a los que consiguen tener acceso a sus derechos como ciudadanos, especialmente en lo que concierne a servicios de salud y técnicas de modificación corporales. Se entrevistaron principalmente a personas trans y travestis, de quienes se recabaron 391 cuestionarios en la ciudad de Río de Janeiro y su región metropolitana, procedentes de diferentes clases sociales, niveles educacionales y configuraciones de identidad de género, que fueron contactados a través de redes sociales por parte de los entrevistadores. Con el fin de definir las identidades de género de quienes respondieron la encuesta, se usó un método original basado en autodefiniciones, que posteriormente fueron añadidas a 6 categorías para fines de análisis de datos. Este artículo discute las múltiples estrategias utilizadas, por parte de esta población trans en procesos de afirmación de género, para conseguir acceso al uso de hormonas reguladas y/o irregulares, así como procedimientos quirúrgicos.

Personas Transgénero; Identidad de Género; Procedimientos de Reasignación Sexual

Submitted on 07/Jun/2018

Final version resubmitted on 15/Sep/2018

Approved on 10/Oct/2018 
Carrara S, Hernandez JG, Uziel AP, Conceição GMS, Panjo H, Baldanzi ACO, Queiroz JP, D’Angelo LB, Balthazar AMS, Silva Junior AL, Giami A. Body construction and health itineraries: a survey among travestis and trans people in Rio de Janeiro, Brazil. Cad Saúde Pública 2019; 35(4):e00110618.

doi: 10.1590/0102-311XER110618

Where it reads:

Keywords: Transgender Persons; Travestism; Body Builds; Gender Identify

Palavras-chave: Pessoas Transgêneros; Travestismo; Estrutura Corporal; Identidade de Gênero

Palabras-clave: Personas Transgénero; Travestismo; Estructura Corporal; Identidad de Género

It should read:

Keywords: Transgender Persons; Gender Identity; Sex Reassignment Procedures

Palavras-chave: Pessoas Trans; Identidade de Gênero; Procedimentos de Redesignação de Gênero

Palabras-clave: Personas Transgénero; Identidad de Género; Procedimientos de Reasignación Sexual 